KULTURA - MEDIA - TEOLOGIA

ISSN 2081-89-71

2020 nr 41, s. $144-173$

Agnieszka Reszka

Uniwersytet Humanistyczno-Przyrodniczy im. Jana Długosza

w Częstochowie

\title{
Intermedialność utworu muzycznego \\ i jej reprezentacja w punkrockowych utworach zespołu Die Toten Hosen
}

The intermediality of musical work

and its representation in punk rock songs

of Die Toten Hosen

\begin{abstract}
ABSTRAKT
Artykuł skupia się na analizie kwestii intermedialności, relacji muzycznoliterackich oraz ich reprezentacji w punkrockowych utworach niemieckiego zespołu Die Toten Hosen. Tekst przedstawia najważniejsze hasła programowe badań nad intermedialnością oraz literackością i muzycznością tekstu utworu muzycznego.

SŁOWA KLUCZOWE: intermedialność, muzycznoliterackie relacje, utwór muzyczny, kryteria literackości, muzyka punk rockowa
\end{abstract}

\begin{abstract}
The article concerns problem of intermediality, relations between music and literature and theirs representation in punk rock songs of German band Die Toten Hosen. The short thesis tries to present briefly the result of research into intermediality and the relations between music and literature in the text of musical work.
\end{abstract}

\section{KEYWORDS:}

intermediality, relations between music and literature, musical work, the literary quality of the work, punk rock music

\section{HYBRYDOWY CHARAKTER UTWORU MUZYCZNEGO}

Utwór muzyczny wraz z tekstem łączy przekaz słowny z wykonaniem instrumentalnym. Tekst literacki funkcjonuje $\mathrm{w}$ ścisłym związku $\mathrm{z}$ warstwą melodyczną, zarówno przy akompaniamencie instrumentów muzycznych, jak również a cappella. Do okresu określanego w badaniach literackich mianem czasów 
ponowoczesnych ${ }^{1}$ słowa piosenek nie mieściły się $\mathrm{w}$ tradycyjnym modelu pojmowania literatury. Doszukiwanie się elementów literackich w tekstach piosenek - zwłaszcza reprezentujących nurt muzyki popularnej - było uznawane za nadużycie i nadinterpretację. Współczesne postulaty badań literackich zmieniają $\mathrm{w}$ istotny sposób przedmiot zainteresowań, na co zwrócił uwagę także Jonathan Culler, który analizując stosunek Stevena Knappa do tekstu literackiego ${ }^{2}$ zauważył, że rozwija on i uzupełnia tradycyjne pojmowanie tekstu literackiego: „Knapp nie podchodzi do zagadnienia wyjątkowości literatury od strony szczególnych rodzajów znaczeń dzieła literackiego - wszak takie nie istnieją - tylko przy pomocy kategorii, którą nazywa «zainteresowaniem literacki$\mathrm{m}{ }^{\prime \prime 3}$. Dzieło literackie straciło na przełomie XX i XXI wieku swój uprzywilejowany charakter jako główny przedmiot badań na korzyść innych „przedmiotów kulturowych"'.

Kwestia cech literackich utworu - nie tylko tekstu, ale również „produktu” sztuk audiowizualnych - stała się ważnym zagadnieniem badań komparastyki literackiej, kulturowej oraz studiów nad intertekstualnością i intermedialnością tekstów kultury ${ }^{5}$. Andrzej Hejmej przedstawiając wybrane utwory poetyckie podkreśla możliwość powiązania ich z innym medium, czyli muzyką: „Teksty literackie (czy szerzej: teksty słowne), które mogą stać się elementami kompozycji muzycznych, przejawiają ku temu potencjalną gotowość tak w płaszczyźnie

\footnotetext{
${ }^{1}$ Zob. A. Regiewicz, J. Warońska, Widowiskowość i audiowizualność w dobie ponowoczesności, Częstochowa 2012, s. 7-9.

${ }^{2}$ Jonathan Culler powołuje się na publikację Stevena Knappa Literary Interest: The Limits of Anti-Formalism (Cambridge 1993).

${ }^{3}$ J. Culler, Literatura w teorii, przeł. M. Maryl, Kraków 2013, s. 37.

${ }^{4}$ Tamże, s. 35.

${ }^{5}$ Istnieje dużo publikacji na temat przełomu kulturowego $\mathrm{w}$ badaniach literackich, na uwagę zasługują m.in.: B. Badzioch-Bryła, G. Pietruszewska-Kobiela, A. Regiewicz, Literatura-nowe media. Homo irretitus w kulturze literackiej XX i XXI wieku, Częstochowa 2014; P. Bourdieu, Reguły sztuki. Geneza i struktura pola literackiego, przeł. A. Zawadzki, Kraków 2001; C. Geertz, Dzieło i życie. Antropolog jako autor, przeł. E. Dżurak, S. Sikora, Warszawa 2000; tenże, Interpretacja kultur. Wybrane eseje, przeł. M.M. Piechaczek, Kraków 2005; D. Higgins, Nowoczesność od czasu postmodernizmu oraz inne eseje, wybór, oprac. i posł. P. Rypson, Gdańsk 2000; M.P. Markowski, R. Nycz (red.), Kulturowa teoria literatury. Główne pojęcia i problemy, Kraków 2012; J.E. Müller, Intermedialität. Formen moderner kultureller Kommunikation, Münster 1996; T. Walas, R. Nycz (red.), Kulturowa teoria literatury 2. Poetyki, problematyki, interpretacje, Kraków 2012.
} 
semantycznej, jak i, zwłaszcza, w warstwie brzmieniowej"6. W odniesieniu do analizy tekstów utworów muzycznych w kontekście ich literackości (lub jej braku) szczególnie interesujące i uzasadnione ze względu na symbiozę i wzajemne przenikanie się dwóch sztuk - literatury i muzyki - jest spojrzenie na nie z perspektywy intermedialnej.

Termin „intermedia” został wprowadzony do analizy dzieła literackiego przez Dicka Higginsa, który powołał się na prace Samuela Taylora Coleridga z 1812 roku, aby określić charakter utworów niemieszczących się w ramach jednego tylko medium, ale będących w obszarze między środkami wyrazu już istniejącymi ${ }^{7}$. Higgins jednocześnie oponuje przeciw niewłaściwemu stosowaniu tegoż pojęcia:

Sam termin, jak zresztą miałem nadzieję, w krótkim czasie zaczął żyć własnym życiem. W żadnym wypadku nie był on moją prywatną własnością. Został podchwycony i używany, często także niewłaściwie gdy mylono go z terminem „mieszane środki wyrazu". Ten ostatni jest terminem sędziwym, wziętym z prac krytycznych o sztuce i odnosi się do dzieł wykonanych za pomocą więcej niż jednej techniki [...]. Natomiast w intermediach element wizualny (obraz) jest pojęciowo stopiony ze słowami ${ }^{8}$.

Kwestia badania intermedialności utworów literackich, na co zwrócił uwage również Higgins, nie ogranicza się w czasie (lata sześćdziesiąte XX wieku), lecz ma wciąż aktualny wymiar. Obszerny i elastyczny zakres terminu nadal jednak budzi wątpliwości. Hejmej zauważa, że mimo szerokiego zakresu znaczenia i dużej frekwencji stosowania we współczesnej humanistyce paradygmatu intermedialności, nie jest on jednoznaczny i budzi kontrowersje:

Wskutek rozbieżnych konceptualizacji rodzi on bądź bezgraniczny optymizm badawczy (kategorię tę uznaje się za niezbędną w opisie współczesnego świata współczesnej kultury i komunikacji kulturowej), bądź zachowawcze myślenie (akceptuje się myślenie, ale wyłącznie w sytuacji interpretowania zjawisk współczesnej sztuki), bądź też - w skrajnych przypadkach - surową krytykę (w tym wypadku teorie intermedialności traktuje się jako efekt przejściowej mody naukowej podbijającej notowania w środowisku humanistów) ${ }^{9}$.

\footnotetext{
${ }^{6}$ A. Hejmej, Muzyczność dzieła literackiego, Wrocław 2001, s. 161.

${ }^{7}$ Zob. D. Higgins, Intermedia i inne eseje, przeł. P. Rypson, Warszawa 1985, s. 19.

${ }^{8}$ Tamże, s. 20-21.

${ }^{9}$ A. Hejmej, Komparatystyka. Studia literackie - studia kulturowe, Kraków 2013, s. 98.
} 
Hejmej opisując przestrzeń intermedialności w najnowszych badaniach kulturowych i literackich (szeroko rozumianej współczesnej humanistyki), koncentruje się na przedstawieniu stanowiska tzw. szkoły kanadyjskiej oraz niemieckiej, a także na teoriach głoszonych przez Jensa Schrötera, Jürgena Ernsta Müllera, Dicka Higginsa oraz Wernera Wolfa, które dotyczą nowego literaturoznawstwa ${ }^{10}$. Intermedialność lub jak proponują badacze szkoły kanadyjskiej „intermedialności" (procesy występujące w liczbie mnogiej) ${ }^{11}$, odnosi się do różnych zjawisk artystycznych i kulturowych zachodzących w otaczającej nas rzeczywistości medialnej i zmediatyzowanej, która tworzy nową estetykę intermedialności, „zrywającej jednocześnie z różnorodnymi tradycjami «czystych» estetyk, i estetyk «eklektycznych»” oraz popiera „wszelkie możliwe związki i fuzje sztuk, do których docho-

Intermedialność lub jak proponują badacze szkoły kanadyjskiej „intermedialności” (procesy występujące w liczbie mnogiej), odnosi się do różnych zjawisk artystycznych i kulturowych zachodzących w otaczającej nas rzeczywistości medialnej i zmediatyzowanej, która tworzy nową estetykę intermedialności, „zrywającej jednocześnie z różnorodnymi tradycjami «czystych» estetyk, i estetyk «eklektycznych»" oraz popiera "wszelkie możliwe związki i fuzje sztuk, do których dochodziło od starożytności po wiek XXI"

dziło od starożytności po wiek XXI"12. Hejmej podkreśla, że konsekwencją takiego stanowiska odnośnie do nowych badań literaturoznawczych jest konieczność holistycznego, eklektycznego spojrzenia na wytwory sztuk artystycznych w zmediatyzowanej nowoczesnej rzeczywistości, które nie istnieją w oderwaniu od siebie, lecz wzajemnie na siebie oddziałują:

\footnotetext{
${ }^{10}$ Tamże, s. 97-113.

${ }^{11}$ Por. tamże, s. 98.

${ }^{12}$ Tamże, s. 99.
} 
Tego rodzaju ujęcia prowadzą w istocie do nader oczywistej konkluzji: nie istnieje wyłącznie świat tekstów, wyłącznie świat obrazów, wyłącznie świat muzyki, czyli światy poszczególnych, wyizolowanych (starych i nowych) mediów czy - jeśli posłużyć się formułą Jürgena E. Müllera - „mediów-monad”. Rzeczywistość artystyczna to raczej ślad, mediatyzacja, zapośredniczenie, „reprezentacja reprezentacji”, co szczególnie eksponuje sztuka wraz z nastaniem epoki nowoczesności ${ }^{13}$.

Ważnym problemem badawczym studiów intermedialnych są wzajemne relacje literatury i muzyki. Tomasz Górny w monografii Polifonia. Od muzyki do literatury przytacza między innymi kanoniczny już model metodologiczny Stevena Paula Schera wzajemnego stosunku powyższych mediów ${ }^{14}$. Scher sklasyfikował trzy grupy relacji: „literaturę w muzyce”, „muzykę i literaturę” oraz „muzykę w literaturze"15. Szczególnie interesujące dla poniższego artykułu są pierwsza i druga kategoria, które zakładają wprowadzenie sensów literackich do muzyki, także programowej, a za taką z pewnością należy uznać muzykę punkrockową (pierwsza) oraz analizowanie współwystępowania dwóch mediów zwłaszcza w odniesieniu do muzyki wokalnej (druga) ${ }^{16}$. Opierając się na metodologii Schera, swoją wykładnię relacji muzyczno-literackich opracował Andrzej Hejmej, który wyróżnił trzy kategorie muzyczności dzieła literackiego. W muzyczności I, jak zauważył, „[...] chodzi nie o immanentne ukształtowanie fonetyczne jakiegoś języka, lecz o nadane w sposób jednostkowy uporządkowanie w sferze brzmieniowości danego tekstu literackiego, nie o onomatopeję [...], lecz o konkretną sytuację jej artystycznego przejęcia, o typ procesu literackiej rekontekstualizacji”" ${ }^{17}$. Muzyczność II to przede wszystkim analiza wykorzystania elementów muzycznych jako tematów w dziele literackim, natomiast III kategoria zajmuje się badaniem kontekstu konstrukcyjności kompozycji muzycznych w jego obrębie ${ }^{18}$.

Magdalena Wasilewska-Chmura analizując zjawisko przestrzeni intermedialnej literatury i muzyki, wskazała również na rozwinięcie modelu Schera przez innego wybitnego literaturoznawcę zajmującego się zjawiskiem muzyczności

\footnotetext{
${ }^{13}$ Tamże, s. 113.

${ }^{14}$ T. Górny, Polifonia: od muzyki do literatury, Kraków 2017, s. 24.

${ }^{15}$ Por. tamże, s. 25-26.

${ }^{16}$ Por. tamże.

${ }^{17}$ A. Hejmej, Muzyczność..., dz. cyt., s. 59.

${ }^{18}$ Por. tamże, s. 59-67.
} 
literatury, przez Wernera Wolfa ${ }^{19}$. Wprowadził on, w nawiązaniu do kategoryzacji Schera, pojęcie intermedialności jawnej, inaczej wielomedialności (bezpośredniej), w której mieści się pojęcie „muzyki i literatury” oraz ukrytej (pośredniej) obejmującej „literaturę w muzyce” $\mathrm{i}$ „muzykę w literaturze” ${ }^{20}$. W ramach intermedialności ukrytej wyodrębnił imitację (odniesienie implicytne), tematyzację (odniesienie eksplicytne) oraz ewokację muzyki wokalnej przez cytat lub aluzję.

W studiach intermedialnych dotyczących relacji muzyki i literatury większą popularnością cieszy się analiza zjawiska muzyczności dzieła literackiego, jednakże również drugi proces - literackość utworu muzycznego - także doczekał się własnych opracowań ${ }^{21}$. Wasilewska-Chmura zaznacza asymetrię relacji semiotycznych pomiędzy tymi obydwoma mediami. Różnice wynikają z charakteru muzyki i literatury: „Muzyka opiera się na eksplicytnej strukturze kombinatorycznej i peryferyjnych konotacjach; w poezji z kolei eksplicytne są konotacje, a struktura poetycka niejako ukryta, zmienna pod względem kompleksowości. [...] Muzyka w tym ujęciu nie jest pozbawiona możliwości generowania znaczeń, lecz dzieje się to na poziomie wypowiedzi, nie słownika"22. Pisząc o asemantyczności muzyki, Tomasz Górny przedstawił krótką chronologię analizy tego zjawiska, łącznie z hermeneutyką muzyczną. Podkreślił skomplikowany i niejednoznaczny charakter muzyki, która częściowo nie jest pozbawiona semantyki:

Powstały bardzo sprawne narzędzia opisu uwikłań semantycznych muzyki, jednak badacze stale przyjmowali i przyjmują założenie o prymarnej apojęciowości sztuki dźwięków, przez co dochodzi do poznawczego pęknięcia: z jednej bowiem strony mówi się o tym, że istota muzyki polega na jej asemantyczności i tym, co przekracza racjonalność, z drugiej zaś podejmuje się rozmaite próby wytłumaczenia tego, że w odbiorze łączymy tworzywo muzyczne z różnym znaczeniem ${ }^{23}$.

${ }^{19}$ Por. W. Wolf, The Musicalization of Fiction: A Study in the Theory and History of Intermediality, Amsterdam - Atlanta 1999.

${ }^{20} \mathrm{Za}$ : M. Wasilewska-Chmura, Przestrzeń intermedialna literatury i muzyki: muzyka jako model i tworzywo w szwedzkiej poezji późnego modernizmu i neoawangardy, Kraków 2011, s. 65.

${ }^{21}$ Wśród polskich publikacji zajmujących się tematyką literackości i muzyczności należy tu wymienić poza przytoczonymi wcześniej tytułami m.in.: A. Gwóźdź (red.), Pogranicza audiowizualności: parateksty kina, telewizji i nowych mediów, Kraków 2010; A. Regiewicz, J. Warońska, A. Żywiołek, Muzyka w czasach ponowoczesnych, Częstochowa 2013.

${ }^{22}$ M. Wasilewska-Chmura, dz. cyt., s. 61.

${ }^{23}$ T. Górny, dz. cyt., s. 21. 
Już od dawna podejmowane były próby nadania utworowi muzycznemu znaczenia. Dzieje się tak zwłaszcza w przypadku muzyki programowej, w której tekst literacki koreluje z linią melodyczną. Górny wymienił tutaj między innymi IX Symfonię Ludwiga van Beethovena z Odq̨ do radości. Funkcję programową, podobnie jak muzyka klasyczna, mają również utwory współczesne (m.in. rap, hip-hop) lub z drugiej połowy XX wieku, zwłaszcza o tak żywiołowym i buntowniczym charakterze jak punk rock, który reprezentował ideologię negacji i rebelii całego pokolenia. Wasilewska-Chmura stawia pytanie dotyczące atrakcyjności muzyki, która chociaż sama jest asemiotyczna, przyciąga inne media:

Na poziomie znaczeń relacje literatury i muzyki są skomplikowane głównie z powodu nierozwiązanego jednoznacznie problemu znaczenia w muzyce. Jak wynika z wcześniejszych rozważań, semiotyka nie zdołała wyjaśnić fenomenu znaczenia muzyki. Stwierdzono jedynie, że w przeciwieństwie do języka znaki muzyki pozbawione są funkcji denotowania, a pewne nieokreślone znaczenia (konotacje) mogą się pojawiać na poziomie znaków wyższego rzędu, które należą do muzyki jako systemu nadbudowanego, a nie jej materiału (systemu dźwiękowego) ${ }^{24}$.

Andrzej Hejmej również zastanawia się, w jaki sposób literatura uwodzi muzykę i jednocześnie jak muzyka używa literatury oraz, jaki jest cel adaptacji tekstu literackiego przez tekst muzyczny i jak one współistnieją w jednym utworze ${ }^{25}$. Odpowiedzi nie są jednak ani oczywiste ani proste, ponieważ jego zdaniem: „Zagadnienie tekstu literackiego w przestrzeni muzyki jest tak rozległe i historycznie pokomplikowane, iż trudno je zamknąć w teoretycznym opracowaniu książkowy-

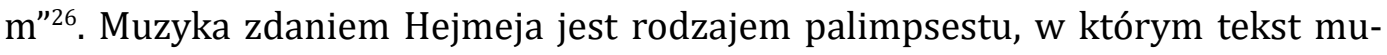
zyczny nakłada się na tekst słowny lub - rzadziej - odwrotnie.

Zespolenie muzyki i literatury jest tak ścisłe, że trudno wyobrazić sobie, aby ważne programowe utwory, tzw. protest songi młodych pokoleń, istniały tylko i wyłącznie w warstwie melodycznej bez słów i oczywiście odwrotnie. Tekst w muzyce rockowej, a zwłaszcza w jego politycznie i społecznie zaangażowanym nurcie punkrockowym, odgrywa ważną rolę i stanowi nieodzowny składnik przekazu. Zagadnieniem literackości tekstów muzycznych (na przykładzie utworów

\footnotetext{
${ }^{24}$ M. Wasilewska-Chmura, dz. cyt., s. 72.

${ }^{25}$ Por. A. Hejmej, Muzycznośćc.., dz. cyt., s. 195.

${ }^{26}$ Tamże.
} 
rockowych) zajmowali się m.in. Mirosław Pęczak oraz Jerzy Wertenstein-Żuławski, redaktorzy publikacji Spontaniczna kultura młodzieżowa. Wybrane zagadnie$n i a^{27}$. Przyznając wyjątkowe miejsce w obszarze sztuki artystycznej oraz roli, jaką odgrywają utwory muzyczne w dziedzinie kształtowania osobowości ich odbiorców, odrzucają jednak cechę literackości tych tekstów:

\title{
Tekst w muzyce rockowej, a zwłaszcza w jego politycznie i społecznie zaangażowanym nurcie punkrockowym, odgrywa ważną rolę i stanowi nieodzowny składnik przekazu.
}

\begin{abstract}
Należałoby zadać najprzód dramatyczne pytanie: czy tekst piosenki rockowej jest tekstem literackim? Skoro pytanie zostało zadane, sprawa wygląda na kontrowersyjną. Nie mamy bowiem wątpliwości, że tekst piosenki poetyckiej byłby tekstem literackim, choć zazwyczaj nie jest to literatura najwyższego, wbrew pozorom, lotu. Wątpliwości te muszą się pojawić, gdy mamy przed sobą tekst piosenki rockowej. Generalnie trzeba założyć nieliterackość, czy raczej pozaliterackość takich tekstów, nawet wówczas, gdy starają się one być, jak teksty Lecha Janerki, literackie. Nie wyklucza to obecności elementów literackości i one to w pierwszym rzędzie świadczą o kulturowej zależności ${ }^{28}$.
\end{abstract}

W sprzeczności do powyższej konkluzji jest więc decyzja Akademii Szwedzkiej z roku 2016 o przyznaniu literackiej Nagrody Nobla amerykańskiemu pieśniarzowi Bobowi Dylanowi, z uzasadnieniem "for having created new poetic expressions within the great American song tradition” („za tworzenie nowych form poetyckiej ekspresji w ramach wspaniałej tradycji amerykańskiej pieśni") ${ }^{29}$.

${ }^{28}$ Tamże, s. 257. 
Powstaje więc rozdźwięk między tradycyjnym pojmowaniem literatury - za Pęczakiem i Wertensteinem-Żuławskim - według którego tekst piosenki nie jest zasadniczo tekstem literackim a spojrzeniem z perspektywy badań intermedialnych, proponujących, aby uznać go za pełnoprawny utwór literacki, który również może mieć bardziej złożoną formę wyrazu artystycznego z przypisanymi do niej znamionami wypowiedzi literackiej (m.in. rytm, rym, funkcja poetycka oraz ekspresywna). Kwestia właściwego sklasyfikowania tekstu, jego przynależności do literatury, jest pytaniem, które stawiane było tekstowi między innymi przez formalistów, strukturalistów czy dekonstrukcjonistów.

Odwołując się do wyróżniających cech literackości w rozumieniu Jonathana Cullera, można posłużyć się nimi jako argumentami potwierdzającymi w pewnym stopniu literacki charakter tekstu piosenek, a przynajmniej nie negującymi ich nie tylko muzycznej, ale także literackiej wartości. Badacz wymienił pięć charakterystycznych cech literatury. Poza wysunięciem języka na pierwszy plan wspomina również o funkcjach literatury, która jest integracją języka, fikcją, przedmiotem estetycznym, a także tworem intertekstualnym i autotelicznym ${ }^{30}$. Uznając je za cechy wyróżniające zarówno utwór prozatorski, jak również liryczny, można spróbować wykazać, że mogą się one odnosić także do utworu muzycznego w przypadku piosenek, w których tekst ma wartość nadrzędną lub zbliżoną do warstwy dźwiękowej. Elementy literackie można odnaleźć w tekście (przedstawiany i opowiadany przez podmiot liryczny temat, elementy fabuły, przekaz stanu emocjonalnego) oraz w jego strukturze - formie (rytm, zastosowane przez autora rymy), jak również użytych środkach językowych (świadome nawiązanie do symboli, użyte metafory, aluzje). Te wszystkie przesłanki przyczyniają się do nadania piosence - przynajmniej w odniesieniu do niektórych jej twórców - wyjątkowej rangi utworu słownego wzbogaconego ścieżką dźwiękową, połączonego z prezentacją artystyczną (teledysk lub inscenizacja podczas koncertu). Odwołując się do zasadniczego wyróżniku literackości tekstu, czyli braku znaczenia praktycznego wypowiedzi ${ }^{31}$ należy zauważyć, że słowa piosenek mają zdecydowanie charakter estetyczny, propagandowy (ale nie utylitarny), polityczny, mogą być również formą artystycznej kreacji autora (także zamierzonego szokowania

${ }^{30}$ Por. J. Culler, Teoria literatury. Bardzo krótkie wprowadzenie, przeł. M. Bassaj, Warszawa 1998, s. 27-53.

${ }^{31}$ Por. tamże, s. 32. 
odbiorcy). Piotr Pierzchała analizując tekst piosenki popularnej, określił jej przekaz mianem kodu słowno-muzycznego ${ }^{32}$.

Łukasz Mackiewicz w tekście Cechy dzieła literackiego - co sprawia, że tekst jest dziełem „literackim”? zauważył, że kwestia literackości jest zagadnieniem wielowymiarowym, stale ewoluującym, i niestety nie zawsze właściwie rozumianym:

Jak widać, literackość wymyka się definicjom, jest zjawiskiem bardzo złożonym i subtelnym. Być może dlatego początkujący twórcy mają duże trudności z jej uchwyceniem i często sięgają po przestarzałe środki, aby wyraźnie ugruntować pozycję tekstu jako dzieła literackiego. Niestety najczęściej oznacza to wykorzystanie zbyt topornych narzędzi:

- rymu;

- przesadnej interpunkcji (nieszczęsny wielokropek...);

- zużytych metafor, które mamy w pamięci od czasów szkolnych;

- skonwencjonalizowanych i banalnych symboli.

Tymczasem nie tędy prowadzi droga do literackości!

Tworzenie literatury opiera się na twórczym korzystaniu z literackich wzorców, dopasowywaniu ich do bieżącej wrażliwości czytelniczej oraz poszukiwaniu nowych, unikatowych środków wyrazu ${ }^{33}$.

Chociaż tekst utworu muzycznego nierzadko jest bliższy sferze profanum niż sacrum, można spróbować zinterpretować go jako swoistą formę hybrydy tekstowej, zawierającej elementy epickie (opowieść budowana przez autora tekstu) i liryczne (odwoływanie się do emocji, melodyjność, powtarzalność refrenu). Jak zauważył Grzegorz Grochowski, cechą tego typu tekstów jest gatunkowa niejednorodność, ponieważ „granice pomiędzy obszarami podporządkowanymi różnym funkcjom przebiegają «w poprzek» poszczególnych tekstów”34.

Utwór muzyczny, a zwłaszcza analizowana tutaj piosenka punkrockowa, jest specyficzną formą wypowiedzi artystycznej i literackiej. Poza zewnętrznymi, strukturalnymi elementami - czyli zachowaniem rytmu, czasem także rymu, melodyjnością, symboliką, podziałem na zwrotki i powtarzający się refren - realizuje

${ }^{32}$ Por. P. Pierzchała, Polska piosenka pop jako tekst w tekście kultury: na przykładach z pierwszej dekady XXI wieku, Katowice 2016, s. 8.

${ }^{33}$ 七. Mackiewicz, Cechy dzieła literackiego - co sprawia, że tekst jest dziełem „literackim”?, http://www.ekorekta24.pl/cechy-dziela-literackiego-co-sprawia-ze-tekst-jest-dzielemliterackim/ (dostęp 04.01.2020 r.).

${ }^{34}$ G. Grochowski, Tekstowe hybrydy. Literackość i jej pogranicza, Wrocław 2000, s. 20. 
przypisane jej funkcje, m.in. emotywną (wyrażenie ekspresji autora, jego stosunku do otaczającej rzeczywistości), impresywną (wywieranie wpływu na odbiorcę), informacyjną (zwłaszcza w przypadku wykonawców zaangażowanych politycznie czy społecznie) oraz ludyczną (rozrywkową, emocjonalną). W funkcji komunikatywnej utworu rockowego ważną rolę odgrywają słowa. Wspomniani badacze, Mirosław Pęczak oraz Jerzy Wertenstein-Żuławski, podkreślają dużą zależność tematyki utworów muzycznych od otaczającej rzeczywistości społeczno-politycznej oraz kultury danego państwa:

Sytuacja kultury rockowej wydaje się typowa dla każdego przedsięwzięcia spontanicznego tj. takiego, które wynika z potrzeby i nieskrępowanego wyboru określonego sposobu uczestniczenia w kulturze, a nie jest wynikiem odgórnie narzuconego przymusu. Teksty rockowe ujawniają w czystej niemal postaci paradoksy myślenia potocznego, charakterystyczne dlań stereotypy, ale stanowią też wyraz określonych postaw. Autor tekstu rockowego pragnie mówić prawdę, albo chce poruszać umysłami. Dlatego w większości tekstów rockowych odnajdujemy nieufność do otaczającego świata, protest przeciw niesprawiedliwości, poszukiwanie prawdy. Okazuje się jednak, że tyle samo przykładów świadczy o względnej samodzielności poszukiwań, co o poważnych uwikłaniach w kwestionowaną rzeczywistość społeczną ${ }^{35}$.

Tekst utworu muzycznego to także istotny element składowy struktury dzieła muzycznego. Piotr Piesiewicz analizując formalno-prawne uwarunkowania utworów muzycznych, wymienił słowa na pierwszym miejscu wśród pozostałych składników (czyli melodii, harmonii oraz rytmu) ${ }^{36}$. Dzieląc teksty na dwie grupy w zależności od intencji ich autora/autorów - na literackie (powstałe niezależnie od warstwy dźwiękowej, tekst może funkcjonować rozłącznie z muzyką) oraz słowno-muzyczne (integralnie związane $\mathrm{z}$ ich instrumentalnym wykonaniem), dostrzegł ich wspólną cechę, czyli słowa jako oryginalny sposób wyrazu twór$\mathrm{cy}^{37}$. Połączenie oryginalności, intencjonalności, ekspresji oraz zazwyczaj (poza piosenkami reklam) brak funkcji praktycznego zastosowania tekstu utworu muzycznego, to argumenty świadczące o literackim charakterze dzieła muzycznego, mniej lub bardziej zrealizowanego artyzmu ich autora lub wykonawcy. Analiza intermedialna w odniesieniu do utworów muzyczno-literackich ma więc swoje uzasadnienie, zwłaszcza w odniesieniu do kategorii „literatury w muzyce”.

\footnotetext{
${ }^{35}$ M. Pęczak, J. Wertenstein-Żuławski., Tekst..., dz. cyt., s. 261.

${ }^{36}$ Por. P.F. Piesiewicz, Utwór muzyczny i jego twórca, Warszawa 2009, s. 32-33.

${ }^{37}$ Por. tamże, s. 36.
} 


\section{MUZYKA PUNKROCKOWA JAKO MUZYKA PROGRAMOWA - GENEZA I GŁÓWNE HASŁA}

Jak zostało już wspomniane, muzyka programowa (gdzie tekst jest co najmniej równie ważnym przekazem, jak współistniejąca z nim melodia) - a do tej grupy należy z pewnością zaliczyć niektóre zespoły i utwory punkrockowe - jest ściśle zespolona pod względem słowno-melodycznym. Przyczyna tego zjawiska tkwi w genezie punk rocka, muzyki buntu, odrzucenia norm i awangardy. Klasyfikacja utworów muzycznych jest zagadnieniem bardzo obszernym i wymaga gruntownej wiedzy zarówno dotyczącej muzykologii, literaturoznawstwa, jak również antropologii kulturowej i socjologii ${ }^{38}$. Szczególnie interesujące jest spojrzenie intermedialne na muzykę punkrockową, której reprezentatywnym przedstawicielem - i co ważne wciąż aktywnie tworzącym muzykę i rozwijającym swój warsztat twórczy - jest niemiecki zespół Die Toten Hosen.

Punk rock - jako muzyka buntu, gloryfikacji anarchii oraz kontestacji państwa, religii i ogólnie przyjętych norm - powstał w połowie lat siedemdziesiątych w Wielkiej Brytanii oraz w Stanach Zjednoczonych. Podstawowym motywem pojawiającym się we wczesnych utworach punkrockowych był słynny slogan Johny'ego Rottena, wokalisty zespołu Sex Pistols - „No future / No future / No future for you” („Nie ma przyszłości / Nie ma przyszłości / Nie ma przyszłości dla ciebie”) ${ }^{39}$. Samo znaczenie słowa „punk” w języku angielskim jest pejoratywne, oznacza chuligana, kogoś bezwartościowego. Johny Rotten - jak zauważył badacz muzyki rockowej Steve Turner - „[...] przedstawiał się jako osoba moralnie

${ }^{38}$ Problematyce tej poświęcono liczne opracowania, szczególnie interesujące są m.in.: D. Boucher, Dylan i Cohen. Poeci rocka, przeł. J. Łoziński, Łódź 2016; G. Castaldo, Ziemia obiecana. Kultura rocka 1954-1994, przeł. J. Uszyński, Kraków 1997; D. Diederichsen, Über Pop-Musik, Köln 2014; S. Turner, Głód niebios. Rock \& roll. W poszukiwaniu zbawienia, przeł. T. Bieroń, Kraków 1997. Na temat muzyki rockowej w państwach byłego Bloku Wschodniego pisali: D. Michalski, Rock przez cały rock, Warszawa 1990; S. Niedermayr, Ch. Scheib, Im Osten - neue Musik Territorien in Europa. Reportagen aus Ländern im Umbruch, Saarbrücken 2002; P. Zieliński, Scena rockowa w PRL. Historia, organizacja, znaczenie, Warszawa 2005.

${ }^{39}$ Cytat pochodzi z refrenu piosenki God Save the Queen, [w:] Never Mind the Bollocks. Here's the Sex Pistols, Studio Album, 1977. (C) 1977 (P) 1977 A\&M Records Ltd. Jest to sztandarowy utwór zespołu, który nawiązywał do brytyjskiego hymnu narodowego - God Save the Queen. Piosenka została uznana za obrazoburczą, muzycy mieli problemy zarówno z jej dystrybucją jak również transmisją w mediach brytyjskich. Ukazała się jako singiel wydany przez wytwórnię Virgin Records (1977). 
zdeprawowana i ontologicznie zbędna. Był anarchistą i antychrystem. Był leniwy, egoistyczny i pusty. Na scenie wyglądał prawie jak kaleka, mówił i śpiewał histerycznym głosem [...]"40. Mimo to, utwory i sposób kontestacji wiodącej punkrockowej grupy odcisnęły swoje piętno na historii współczesnej muzyki rockowej:

Muzyka Sex Pistols, podobnie jak wczesnego Elvisa Presleya, brała się z „samych trzewi". Słuchacze ich koncertów mieli poczucie, że znajdują się w kuźnicy młodzieżowej kultury. To nie był tylko spektakl, lecz kawałek historii, wydarzenie odzwierciedlające rzeczywiste frustracje bezsilnych ludzi ${ }^{41}$.

Prekursorami alternatywnego rocka byli już w latach sześćdziesiątych Iggy Pop, David Peel oraz zespoły The Who, Velvet Underground oraz MC 5. Zdaniem Gino Castaldo, punk nie był zupełnym zaprzeczeniem dotychczas tworzonej muzyki rockowej czy rock-and-rollowej, lecz stał się raczej kolejną fazą ewolucji, wymuszoną przez sytuację gospodarczą oraz działania polityczne rządów:

Ale prawdą jest również, że punkowcy wcale nie byli jakąś nieznaną naroślą na rockowym drzewie genealogicznym; po dwudziestu latach podjęli ów prymitywny, zbuntowany okrzyk rzucony w początkach rock'n'rolla. Ich głos brzmiał świeżo, choć zarazem dziwnie znajomo; jak żadna inna sztuka rock ponownie potrafił przepędzać społeczne demony ${ }^{42}$.

Do znanych grup punkrockowych należały m.in. w Anglii - poza Sex Pistols The Clash, The Damned, w Stanach Zjednoczonych - Ramones, Blondie, The Talking Heads, Suicide, Patti Smith Group ${ }^{43}$. Lata siedemdziesiąte w historii muzyki punk są określane mianem pierwszej fali, kolejne dziesięciolecie to druga fala punk rocka (ze słynnym sloganem „Punk not dead” - „Punk wciąż żyje”), która przyniosła zmianę jakościową tekstów i ich mocniejszy społeczny przekaz. Zespoły, wśród nich m.in. Dead Kennedys, Bad Religion i Crass, nie tylko pokazywały beznadziejną sytuację młodych, ale także zachęcały fanów do burzenia systemu i aktywnego tworzenia nowej rzeczywistości ${ }^{44}$.

\footnotetext{
${ }^{40}$ S. Turner, dz. cyt., s. 141.

${ }^{41}$ Tamże.

${ }^{42}$ G. Castaldo, dz. cyt., s. 233.

${ }^{43}$ Zob. tamże, s. 231-248.

${ }^{44}$ Zespół Crass propagował m.in. ideologię anarchistyczną.
} 
Zespoły punkrockowe, zwłaszcza te wywodzące się z jego najbardziej agresywnego pierwszego okresu, nie przetrwały długo. Tryb życia prowadzony przez muzyków, wewnętrzne spory, problemy z wydawaniem płyt, a także negowanie zasad funkcjonowania przemysłu muzycznego i rządzących nim komercyjnych reguł przyczyniały się do rozpadu większości zespołów, a także częstych zmian osobowych ich składów.

\section{NIEMIECKI PUNK ROCK I JEGO REPREZENTANCI DIE TOTEN HOSEN}

Dla analizowania kwestii intermedialności utworów muzycznych został wybrany niemiecki zespół Die Toten Hosen, ponieważ zarówno jego historia, jak również wciąż aktualna znacząca siła oddziaływania są istotne dla przedstawienia silnych związków muzyki z literaturą, do których dochodzą jeszcze relacje kulturowe i socjologiczne.

Specyfika sceny punkrockowej i jej zmienność, a także autodestrukcyjne zachowania muzyków podkreślają wyjątkowe miejsce niemieckiej grupy Die Toten Hosen (powszechnie stosowany skrót DTH) ${ }^{45}$. Zespół powstał w Düsseldorfie w 1982 roku, w mieście, które obok Hamburga było w tym okresie najbardziej otwarte na wpływy kulturalne, nowe trendy muzyczne z Anglii oraz Stanów Zjednoczonych ${ }^{46}$. Punk niemiecki, jak zauważył Kai Jessen, na początku lat osiemdziesiątych - z dużym opóźnieniem w stosunku do angielskich czy amerykańskich wzorców - dopiero zaczynał funkcjonować: „Podczas gdy muzyka punkrockowa przeżywała już od dłuższego czasu boom w Londynie i coraz więcej młodych znajdowało się pod jej urokiem, większość miast niemieckich pogrążona była jeszcze w letargu" ${ }^{\prime 7}$. Do innych znanych niemieckich zespołów punkrockowych, które powstały w latach osiemdziesiątych należały (niektóre wciąż istnieją) poza zespołem

${ }^{45}$ Nazwę zespołu - tłumaczoną dosłownie jako „martwe spodnie” - należy potraktować, jako świadomą formę prowokacji, stosowaną przez twórców kultury młodzieżowej czy też powszechnej. W znaczeniu potocznym zwrot „die tote Hose” oznacza ,impotenta”. Oficjalna strona internetowa zespołu DTH: https://www.dietotenhosen.de/ (dostęp 04.01.2020 r.) oraz https:// de-de.facebook.com/dietotenhosen/ (dostęp 04.01.2020 r.).

${ }^{46}$ W Düsseldorfie funkcjonował klub Ratinger Hof, w którym odbywały się najważniejsze imprezy muzyczne, występowały w nim także nowo powstające zespoły punkowe - m.in. DTH.

${ }^{47}$ K. Jessen, Die Toten Hosen. Für immer Punk, München 1997, s. 13. 
DTH także Die Ärzte, Feeling B, The Bates, Dritte Wahl, Böhse Onkelz ${ }^{48}$. Zespół Die Toten Hosen powstał z byłego ZK, krótko (druga połowa lat osiemdziesiątych) używana była również nazwa Die Roten Rosen (Czerwone Róże) ${ }^{49}$. Pierwsze lata działalności były trudne, młodzi muzycy mieli niewielką szansę, aby odnieść sukces, jednak stopniowo grupa zdobyła uznanie, przyciągając na swoje koncerty na przełomie lat osiemdziesiątych i dziewięćdziesiątych tysiące fanów. Muzycy wielokrotnie występowali zagranicą ${ }^{50}$. Po krótkotrwałym zawieszeniu działalności w 1997 roku $^{51}$, z nową energią wrócili do nagrywania płyt i organizowania koncertów.

Funkcjonowanie zespołu, jego stały wzrost popularności jest ciekawym przypadkiem w historii muzyki punkrockowej. Większość grup reprezentujących ten nurt przestała już istnieć lub straciła wiarygodność w opinii fanów. Marka DTH utrzymała się, grupa zdobywa wciąż nowych słuchaczy, przekrój wiekowy uczestników koncertów jest bardzo zróżnicowany. Należy jednak zauważyć, że w państwach niemieckojęzycznych zespół jest traktowany niemalże jak dobro narodowe, produkt eksportowy. Mimo licznych pozytywnych opinii dotyczących drogi rozwoju i ewolucji jego utworów muzycznych, nie brakuje jednak również głosów krytycznych i zarzutów dotyczących komercjalizacji sztuki:

Obecnie zespół DTH stał się znakiem firmowym, tak jak np. Coca Cola, ze swoją imponującą firmą i celem, który nie odpowiada pierwotnemu założeniu: ZYSK i komercja. Gdzie one pozostały, dni takie jak te [aluzja do utworu Tage wie diese - A.R.] i stare piosenki? ${ }^{72}$

${ }^{48}$ Więcej na temat niemieckiej kultury oraz muzyki punkrockowej: IG Dreck auf Papier, Keine Zukunft war gestern: Punk in Deutschland, Berlin 2008; P. Meinert, M. Seeliger, Punk in Deutschland, Sozial- und kulturwissenschaftliche Perspektiven, Bielefeld 2013.

${ }^{49}$ Szczegółowe informacje na temat historii zespołu DTH można znaleźć - poza wspomnianą publikacją Kaja Jessena - w książce Philippa Oehmke, Die Toten Hosen. Am Anfang war der Lärm, Reinbek bei Hamburg 2015 oraz na oficjalnej stronie internetowej zespołu: https:// www.dietotenhosen.de/band/biographie (dostęp 04.01.2020 r.).

${ }^{50}$ Trasy koncertowe m.in. w Stanach Zjednoczonych, Argentynie, Europie Wschodniej oraz w Azji.

${ }^{51}$ Przełomowy 1000-ny koncert DTH (tzw. open-air), który odbył się w 1997 r. na stadionie Rheinstadion w Düsseldorfie - przygotowywany przez wiele miesięcy - okazał się momentem przełomowym w historii zespołu. Podczas koncertu doszło do tragicznego wypadku. W ścisku, który powstał pod sceną zginęła nastolatka z Holandii. Po tym wydarzeniu zespół przez pewien czas nie występował.

${ }^{52}$ Leserkommentare, http://www.taz.de/30-Jahre-Die-Toten-Hosen/!5096509/, http:// www.taz.de/30-Jahre-Die-Toten-Hosen/!5096509/ (dostęp 05.01.2020 r.). 
Zespół posiada własną wytwórnię płytowąą ${ }^{53}$ funkcjonuje jak dobrze zarządzana firma. Jak zauważył Philipp Oehmke, decyzje dotyczące zespołu podejmowane są wspólnie, jednakże decydującą rolę zwyczajowo ma jego lider i jednocześnie wokalista Andreas Frege (pseud. Campino) ${ }^{54}$ :

W strukturze wewnętrznej muzycy Die Toten Hosen uważają się za instytucję demokratyczną. Każdy ma głos, każdy zostanie wysłuchany, teoretycznie każdy może zgłosić veto, a później dyskutują tak długo, aż i tak Campino postawi na swoim. Vincent Sorg producent Die Toten Hosen, który uczestniczył w wielu podejmowanych wspólnie decyzjach podczas nagrywania płyt w studio, określił kiedyś ten stan: „Die Toten Hosen są najlepiej funkcjonującą pozorną demokracją na świecie"55.

Miejsce, które na rynku muzycznym państw niemieckojęzycznych zajmuje punkrockowa grupa DTH, jest z pewnością pozycją wypracowaną, osiągniętą przez świadomie zaplanowane i realizowane działania nie tylko członków zespołu, ale także licznych współpracowników przy akceptacji praw rządzących przemysłem muzycznym. Zarzut dotyczący komercjalizacji jest więc uzasadniony, jednak w obecnej chwili tylko nieliczne niszowe zespoły mogą pozwolić sobie na komfort lekceważenia mechanizmów kierujących promocją, reklamą i sprzedażą produktu, czyli muzyki. Wciąż utrzymująca się pozytywna recepcja utworów zespołu świadczy ponadto o dużym zainteresowaniu odbiorców i nadal istniejącej sile oddziaływania tekstów piosenek, które oczywiście w sposób naturalny ewoluowały również przez rozwinięcie ich zakresu tematycznego oraz wzbogacenie elementami lirycznymi.

\section{KONTEKSTY MUZYCZNO-LITERACKIE UTWORÓW DIE TOTEN HOSEN}

Intermedialny aspekt piosenek niemieckiej grupy punkrockowej można rozpatrywać w odniesieniu do wzajemnych zależności muzyki, warstwy brzmieniowej, języka, tekstu słownego, ale również elementów sztuki audiowizualnej oraz

${ }^{53}$ Jest to firma płytowa: JKP Gmbh \& Co. KG.

${ }^{54}$ Andreas Frege wywodzi się ze znanej niemieckiej rodziny sędziowskiej, do jego przodków należał m.in. Fregehaus w Lipsku. Także pozostali członkowie zespołu, czyli Andreas Meurer (pseud. Andi), Andreas von Holst (pseud. Kuddel), Andreas Breitkopf (pseud. Breiti), Stephen George Ritchie (pseud. Vom) mają raczej mieszczańskie pochodzenie, wychowali się w stosunkowo zamożnych (średnia klasa) rodzinach.

${ }^{55}$ P. Oehmke, dz. cyt., s. 14. 
antropologii kulturowej i obecności tych utworów w nowych mediach (Internet). Najbardziej widoczne są jednak - w przypadku utworu wokalnego - relacje muzyczno-literackie.

W piosenkach DTH prymarny charakter ma melodia, od niej zaczyna się proces tworzenia utworu. $\mathrm{W}$ okresie początkowym istnienia zespołu, odpowiednio do reguł stosowanych w muzyce punkrockowej, charakterystyczna dla niemieckiej grupy była prosta linia melodyczna, z nieskomplikowanym i raczej żywiołowym wokalem, przy skromnej aranżacji utworów z wykorzystaniem gitar elektrycznych, basów i perkusji. W czasie prawie już czterdziestoletniej działalności warsztat instrumentalny bardzo się rozwinął i jak zauważył jeden $\mathrm{z}$ recenzentów najnowszej płyty: „Z muzykami grającymi na instrumentach smyczkowych,

Intermedialny aspekt piosenek niemieckiej

grupy punkrockowej można rozpatrywać w odniesieniu do wzajemnych zależności muzyki, warstwy brzmieniowej, języka, tekstu słownego, ale również elementów sztuki audiowizualnej oraz antropologii kulturowej i obecności tych utworów w nowych mediach (Internet).

dętych, fortepianie zespół Die Toten Hosen przedstawia 21 piosenek w zupełnie nowej szacie dźwiękowej i ujmuje niezwykłym kierunkiem rozwoju"56. Zespół znany jest obecnie z łączenia różnych środków wyrazu oraz form muzyki (folk, muzyka klasyczna, pop i rap), gra także koncerty akustyczne oraz nagrywa w tej wersji płyty ${ }^{57}$.

${ }^{56}$ Neues Album "Alles ohne Strom" Die Toten Hosen ziehen den Stecker, https://www. hr3.de/musik/die-toten-hosen-mit-neuem-album-alles-ohne-strom-die-lyrics-zu-feiern-imregen,tote-hosen-neues-akustik-album-100.html (dostęp 05.01.2020 r.).

${ }^{57}$ Przykładem jest ostatnia płyta zespołu wydana jesienią 2019 roku: Alles ohne Strom, (C) 2019, P 2019 JKP Gmbh \& Co. KG. 
Analizując dorobek zespołu, można raczej mówić o kategorii intermedialnej według Schera - „literatury w muzyce”, warstwa melodyczna jest jednak ściśle związana z przekazem językowym. Jak zauważył Tomasz Górny, Scher stworzył swoją typologię wychodząc z założenia, że muzyka ma esencjalne właściwości, a w związku z tym jest asemantyczna i autoteliczna, natomiast literatura cechuje się dyskursywnością i denotacyjnością i dlatego kategoria „literatura w muzyce” łączy cechy obydwu mediów i „dotyczy dyskursywności w sztuce dźwięku”58. Górny wspomina również, odnosząc się do muzyki klasycznej, że na pewnym etapie powstawania melodii lub ewolucji warsztatu kompozytora, dochodzi do połączenia muzyki z tekstem, gdy autor włącza do swej kompozycji tekst literacki: „Nierzadko w twórczości tej samej osoby dochodziło do łączenia elementów muzyki czystej i programowej" 59 .

Warstwa językowa piosenki nawiązuje w pewnym stopniu do cech „literatury oralnej", którym to terminem posłużył się Walter Jackson Ong dla odróżnienia pierwotnej kultury oralnej od późniejszej piśmiennej ${ }^{60}$. Zdaniem Onga termin ten powinien być raczej zastąpiony pojęciem „czysto oralne formy sztuki” lub „formy sztuki słowa”, ponieważ podstawą jest przekaz ustny, a nie wyłącznie materialny zapis utworu: „Wykonanie oralne można zatem uważać za «głoszenie» [voicings], co odpowiada prawdzie. Na takie przyjęte znaczenie ogólne, będące odniesieniem do wszystkich tworów oralnych, może nakładać się zwyczajowe znaczenie terminu epos: poezja (oralna) epicka"61. Funkcją prymarną tekstu piosenki jest głoszenie $\mathrm{w}$ formie ustnej przekazu, a nie jako libretta $\mathrm{w}$ formie pisemnej. Punk rock - można pokusić się o takie stwierdzenie - nie istnieje bez oralnej prezentacji tekstu, zarówno podczas koncertów, jak również odtwarzania nagrań. Ładunek emocjonalny tekstu musi być wypowiedziany, a nawet wykrzyczany, razem z agresywną i rytmiczną linią melodyczną. Jak zauważył Andrzej Hejmej: „[...] utwór literacki nie pojawia się inkrustacyjnie, ze względu na swój walor brzmieniowy, ponieważ kompozytor chce zachować za wszelką cenę jego znaczenie literackie"62. Tekst może również funkcjonować w przestrzeni pozamuzycznej.

${ }^{58}$ T. Górny, dz. cyt., s. 25-26.

${ }^{59}$ Tamże, s. 21.

${ }^{60}$ Por. W.J. Ong, Oralność i piśmienność. Słowo poddane technologii, przeł. J. Japola, Warszawa 2011, s. 41-42.

61 Tamże, s. 45.

${ }^{62}$ A. Hejmej, Muzyczność..., dz. cyt., s. 198. 
W utworach Die Toten Hosen znaczenie warstwy językowej (przede wszystkim w wykonaniu wokalnym, a nie jako zapisanego tekstu) jest istotne. Melodia, chociaż powstaje pierwsza i niezależnie od tekstu literackiego, ma pewien wpływ na jego kształt, a słowa muszą wejść w relację z muzyką:

Campino pisze swoje piosenki zawsze według jednej reguły: najpierw muzyka, później tekst. Wspólnie z zespołem melodia jest wypracowana, nagrana, a następnie u Campino ciągle i ciągle odtwarzana, tak długo, aż nie powstanie odpowiedni do niej tekst. ${ }^{63}$.

Autorem słów większości piosenek jest lider zespołu ${ }^{64}$. Krytycy muzyczni i dziennikarze zauważają, że słowa piosenek są ich czynnikiem wyróżniającym i mimo, iż muzyka punkrockowa nie należy do zbyt wysublimowanych rodzajów muzyki o wysokiej wartości artystycznej, jednak dbałość o ciekawy tekst, z którym utożsamiają się odbiorcy z pewnością podnosi wartość utworów zespołu. Warstwa językowa zawiera elementy literackie, dostrzegalne są w niej opisy realizujące funkcję poetycką, ekspresywną, ale także impresywną oraz poznawczą. Można dostrzec również elementy retoryczne oraz fatyczne w bezpośrednich zwrotach do odbiorców.

Andreas Frege, który w bardzo ekspresyjny i nierzadko krytyczny sposób przedstawia rzeczywistość polityczną i problemy społeczne, robi to świadomie w celu epatowania nadużyciami i wzbudzenia u słuchaczy oporu wobec otaczającej rzeczywistości. Zdaniem Philippa Oehmke lider zespołu aspiruje do budowania w tekście świata fikcyjnego, który imituje rzeczywistość, a przez to zyskuje większą możliwość oddziaływania na słuchaczy:

$\mathrm{Z}$ drugiej strony, to co posiada Campino, to umiejętność wyrażenia siebie w tekstach, obnażenia się, on podziwia zdolność pisania tekstów, które mają coś wspólnego z życiem i - jego zdaniem - często należą do najlepszych napisanych w języku niemieckim ${ }^{65}$.

${ }^{63}$ S. Wirth, Lit.Cologne. Campino und das Dichten, http://stellwerk-magazin.de/magazin/ artikel/2016-03-23-campino-und-das-dichten (stan z 11.01.2018 r.).

${ }^{64}$ Współautorami tekstów niektórych piosenek są także inni muzycy, piosenkarze czy przedstawiciele świata kultury i sztuki. Zwłaszcza w przypadku ostatnich płyt (np. Ballast der Republik oraz Laune der Natur) udział innych artystów jest istotny, są to m.in.: aktorka Birgit Minichmayr oraz raper Marten Laciny.

${ }^{65}$ P. Oehmke, dz. cyt., s. 299. 
Treść piosenek nie jest jednak tylko i wyłącznie nośnikiem emocji negatywnych. Punk rock dawał muzykom także możliwość swobodnego wyrazu uczuć i postulatów pozytywnych. Marcin Lewandowski podkreśla, że „[...] reprezentanci subkultury punkowskiej oprócz kwestionowania zastanego porządku wartości mają również potrzebę manifestowania i komunikowania swoich odczuć i wrażeń za pomocą słów i frazeologizmów wartościujących dodatnio"66.

Pisanie tekstów nie jest jednak - jak przyznał Campino - czynnością prostą i automatyczną. W jednym z wywiadów w dosyć krytyczny i bezpośredni sposób przedstawił swój sposób pisania: „Kiedy chodzi o pisanie, krążę jak kot koło gorącego mleka" ${ }^{67}$. Proces literacki nie jest więc aktem metafizycznym, duchowym, lecz raczej mozolnym trudem, aby przełożyć własne doświadczenia oraz poglądy na tekst literacki i jednocześnie dopasować słowa do rytmu, instrumentarium istniejącej już melodii, na którą należy nałożyć pasującą do niej warstwę słowną. Frege nie ukrywa, że tworzenie tekstu jest czynnością skomplikowaną i stanowi artystyczne wyzwanie. Niejednokrotnie w wywiadach poruszał kwestię blokady twórczej, stanu niemocy kreowania satysfakcjonujących go nowych utworów: „To jest raczej męczący proces [pisanie tekstów - A.R.] zdradził Campino czterystu obecnym tam osobom z publiczności. Die Toten Hosen rozpoczęły właśnie nagrywanie nowej płyty, a Campino tkwi w trwającym już osiem miesięcy stanie blokady pisania"68. Pomocą w pisaniu piosenek, poza opisem przeżyć oraz bieżących wydarzeń, a także poszukiwaniem inspiracji w literaturze, służy mu prowadzony od kilkudziesięciu lat dziennik. Każdy utwór zamknięty w cyklu tematycznym płyty lub powstały jako samodzielny tekst ma własną genezę. Krytycy zwracają uwagę na różnorodność i zmienność motywów, a także na oryginalne - w niektórych przypadkach - okoliczności powstania piosenek:

Nie ma dla niego żadnej recepty na napisanie tekstu, to się po prostu dzieje. Z powodu niektórych płyt [np. Opium fürs Volk - A.R.] zamknął się nawet na kilka tygodni

${ }^{66}$ M. Lewandowski, dz. cyt., s. 65.

${ }^{67}$ Bei der lit. Cologne „Tote Hosen" - Sänger Campino: Wir machen ein neues Album, https://www.express.de/duesseldorf/bei-der-lit-cologne--tote-hosen--saenger-campino-wir-machen-ein-neues-album-23704206 (dostęp 05.01.2020 r.).

${ }^{68}$ Lit. Cologne. Campino steckt in der Schreibblockade, https://www.ksta.de/kultur/lit-cologne/lit-cologne-campino-steckt-in-der-schreibblockade-23704736 (dostęp 05.01.2020 r.). 
w klasztorze, aby się wyciszyć i stworzyć teksty. Niektóre piosenki powstały w piętnaście minut, a inne pisał przez rok. W ciągu ostatnich kilku lat zmieniły się istotnie zarówno albumy płytowe, jak również teksty piosenek, stały się bardziej przemyślane i wartościowe ${ }^{69}$.

W ciągu prawie czterdziestu lat istnienia zespołu jego utwory, choć nadal wsparte mocnym rockowym brzemieniem, stały się bardziej dojrzałe i wysublimowane $\mathrm{w}$ warstwie tekstowej. Ich problematyka porusza istotne aktualne kwestie społeczne oraz kulturowe, nie unika również spornych kwestii politycznych.

Zakres tematyczny piosenek jest obszerny i podlega stałej ewolucji, aby wskazać elementy literackie można odwołać się do kilku charakterystycznych motywów, które często pojawiają się na płytach zespołu. W najwcześniejszych utworach były to - zgodnie z ideologią punkową - bunt, krytyka przywiązania do materialistycznych wartości gloryfikowanych w Niemczech Zachodnich oraz odrzucenie stylu życia starszego pokolenia (motywy przewodnie takich utworów jak m.in.: Opel-Gang, Armee der Verlierer $\left.{ }^{70}\right)$ :

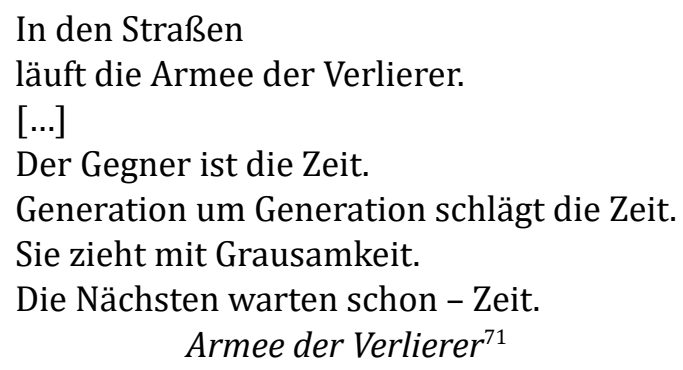

Ważnym elementem była wspólnota młodych ludzi, którzy nie zgadzali się na tryb życia narzucany im przez pokolenie rodziców. Łączyła ich młodość, beztroska i chęć wyróżnienia się z tłumu:

${ }^{69}$ S. Wirth, dz. cyt. (dostęp 11.01.2018 r.).

${ }^{70}$ Utwory zamieszczone na pierwszej płycie DTH: Opel-Gang, Studio Album, 1983 (2. wyd. 2003). (C) 1983, 2003 (P 1983, 2003 JKP Gmbh \& Co. KG.

${ }^{71}$ Tamże, Armee der Verlierer; „Na ulicach/ biegnie armia pokonanych./ [...] Przeciwnikiem jest czas./ Czas wybija pokolenie za pokoleniem./ Nadciąga z okrucieństwem./ Następni już czekają - czas". 
Den Arm aus dem Fenster das Radio voll an

$[\ldots]$

Wir sind die Jungs von der Opel Gang.

Wir haben alle abgehängt.

Opel-Gang ${ }^{72}$

Bunt przeciwko istniejącym strukturom łączył się z pozorną wolnością, jaką dawało poczucie wspólnoty i stosowanie używek:

Wir sind geboren worden, ob wir wollten oder nicht

Von da an ging es abwärts mit unser'm Würfelglück

[...]

Wir haben schon öfters Gras geraucht und wissen, was Koks ist

Und dass es außer Champignons noch and're Pilze gibt

Wir lagen schon bedröhnt auf der Fahrbahn in der Nacht

Um die Sterne mal zu zählen über uns'rer schönen Stadt

Und wir leben ${ }^{73}$

Motywy pojawiające się w najwcześniejszych utworach, czyli bunt i kontestacja norm oraz wartości uznawanych przez starsze pokolenie, zostały z czasem wyparte na dalszy plan i wzbogacone analizą kondycji społeczeństwa niemieckiego. Zespół DTH czynnie - uczestnicząc między innymi w manifestacjach, protestach i politycznych happeningach ${ }^{74}$ - angażuje się w spory polityczne, sprzeciwiając się nacjonalizmowi i wciąż popularnemu w powojennych Niemczech nazizmowi:

${ }^{72}$ Tamże, Opel-Gang; „Łokieć za oknem, radio na cały regulator/ [...] Jesteśmy chłopakami z gangu Opla./ Wszystkich zostawiliśmy w tyle".

${ }^{73}$ DTH, Und wir leben, [w:] Opium fürs Volk, Studio Album, 1996 (2. wyd. 2007). (C) 1996, 2007 (P 1996, 2007 JKP Gmbh \& Co. KG; „Urodziliśmy się, nieważne czy tego chcieliśmy czy nie/ od tego momentu było już tylko gorzej z naszym przypadkowym szczęściem/ [...] Paliliśmy już trawkę i wiemy, co to koks/ i to, że oprócz pieczarek są jeszcze inne grzybki/ Zdarzyło nam się już także leżeć w nocy w otępieniu na ulicy,/ aby policzyć gwiazdy nad naszym pięknym miastem".

${ }^{74}$ Do akcji, w których wzięli udział członkowie zespołu należą m.in.: protesty przeciwko podpalaniu mieszkań imigrantów (Bonn i Frankfurt am Main, 1992 r.), a także głośne w 2017 roku wystąpienia Anti-Pegida [pol. Antypegida] przeciwko faszyzacji Europy (demonstracja z udziałem DTH w Dreźnie). 


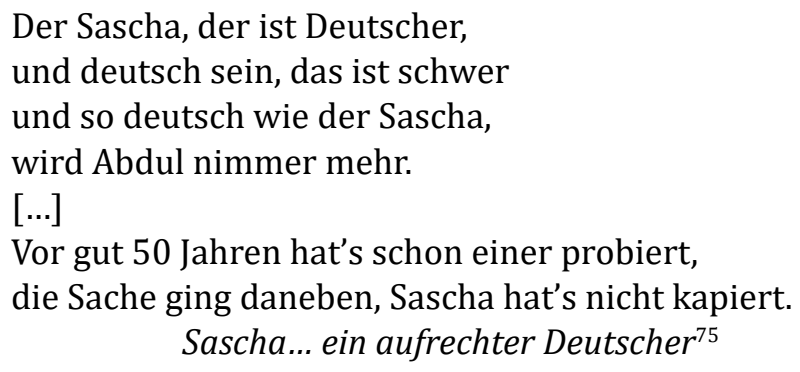

W tekstach poruszane są także kwestie egzystencjalne związane z religią, usytuowaniem Boga we współczesnym świecie oraz przestrzeganiem zasad moralnych. Andreas Frege szuka odpowiedzi na pytanie o istotę człowieczeństwa, złożoność natury ludzkiej oraz sens istnienia:

Du fragst mich, wie ich heiße, weil Du meinst, ich bin Dir fremd

Laß Dir etwas von mir erzählen, dann merkst Du, wer ich bin

Ich habe viele Gesichter, und ich kann mich gut verstellen

[...]

Mein Name ist Mensch, ich weiß, dass Du mich kennst

Ich bin $\mathrm{Du}$, Du bist ich, ich bin ein Mensch.

Mensch $^{76}$

Pojawia się także odniesienie - w duchu ewangelickim - do wypełniania obowiązków, życia zgodnego z przykazaniami i ogólnie przyjętymi zasadami etycznymi lub ich odrzucenia:

Wer kann schon sagen, was mit uns geschieht

vielleicht stimmt es ja doch

dass das Leben eine Prüfung ist, in der wir uns bewähren sollen

$[\ldots]$

${ }^{75}$ DTH, Sascha... ein aufrechter Deutscher, [w:] Kauf mich, Studio Album, 1993 (2. wyd. 2007); (C) 1993, 2007 (P 1993, 2007 JKP Gmbh \& Co. KG; „Sasza jest Niemcem, a być „niemieckim" jest trudne/ i tak niemiecki jak Sasza,/ Abdul nigdy nie będzie./ [...] Przed ponad pięćdziesięcioma laty ktoś zrobił już coś podobnego,/ rzecz się powtórzyła, Sasza niczego nie zrozumiał".

${ }^{76}$ DTH, Mensch, [w:] Opium fürs Volk, dz. cyt.; „Pytasz mnie, jak się nazywam, ponieważ uważasz, że jestem Ci obcy/ Pozwól, że opowiem Ci coś o sobie, później rozpoznasz, kim jestem/ [...] Nazywam się człowiek, wiem, że mnie znasz/ Jestem Tobą, Ty jesteś mną, jestem człowiekiem". 
Ich will nicht ins Paradies, wenn der Weg dorthin so schwierig ist ich stelle keinen Antrag auf Asyl, meinetwegen bleib ich hier. Paradies $^{77}$

Piosenki DTH podjęły próbę zmierzenia się z ważnym, ale niestety trudnym problemem ostatnich lat. $\mathrm{W}$ publicznych wystąpieniach, udzielanych wywiadach oraz podczas koncertów członkowie zespołu konsekwentnie rozgraniczają kwestię imigrantów od zagrożenia terrorystycznego ${ }^{78}$. Kryzys zaufania do przedstawicieli innych narodów, realne niebezpieczeństwo wynikające z fanatyzmu religijnego i ataków terrorystycznych nie powinny zdaniem Andreasa Frege determinować stosunku do uchodźców. Problemami naszego czasu są narastające powszechnie na świecie szowinizm i rasizm przy jednoczesnym braku empatii dla innych:

Sie kommen zu Tausenden, doch die Allermeisten

Werden das gelobte Land niemals erreichen

Denn die Patrouillen werden sie aufgreifen

Um sie in unserem Auftrag zu deportieren

Und der Rest, der wird ersaufen

Im Massengrab vom Mittelmeer

Europa $^{79}$

Działalność zespołu zdecydowanie wykracza poza obszar muzyki. Oddziaływanie społeczne zarówno utworów, jak również bezpośrednich akcji podejmowanych przez muzyków można rozpatrywać w kategorii socjologicznej i antropologicznej. Intermedialność lub może raczej transmedialność (zastosowanie nowych mediów) muzyki, literatury i innych dziedzin mogłaby stać się tematem - ponieważ jest to również stosunkowo obszerne zagadnienie - kolejnego tekstu.

${ }^{77}$ Tamże, Paradies; „Kto może już teraz powiedzieć, co się z nami stanie/ a może to prawda,/ że życie jest egzaminem, w którym powinniśmy się sprawdzić/ [...] Ja nie chcę iść do raju, skoro droga jest tak trudna/ nie będę wnioskował o azyl, jeśli o mnie chodzi pozostanę tutaj".

${ }^{78}$ Por. http://www.heute.at/szene/musik/story/-Tote-Hosen--vor-Wien-Gig--Mittelfinger-fuer-Terror--41397655 (dostęp 06.01.2020 r.).

${ }^{79}$ DTH, Europa, [w:] Ballast der Republik, Studio Album, 2012. (C) 2012 (P 2012 JKP Gmbh \& Co. KG.; „Przybywają tysiącami, jednak większość z nich/ Nigdy nie dotrze do Ziemi Obiecanej/ Ponieważ patrole ich wyłapią/ Aby na nasze polecenie ich deportować/ A reszta utonie w masowym grobie w Morzu Śródziemnym". 
Prospołeczne zaangażowanie muzyków z zespołu Die Toten Hosen w akcje charytatywne (m.in. w Afryce), ekologiczne oraz anty-nacjonalistyczne stały się ważnymi postulatami programowymi zespołu. Muzycy współpracują między innymi z organizacjami: Oxfam, Pro Asyl i Kein Bock auf Nazis ${ }^{80}$. Podczas koncertów oraz publicznych wystąpień i wywiadów Andreas Frege, wokalista zespołu i jego rzecznik, przypomina o zagrożeniach związanych z faszyzmem, nawoływaniem do nietolerancji, nienawiści i wrogości wobec obcych. Formą rozliczenia się z nazizmem i upamiętnienia tragicznego losu Żydów z getta warszawskiego oraz tych wszystkich, którzy zostali zamordowani w obozach zagłady były trzy koncerty zorganizowane w październiku 2013 roku w Düsseldorfie (pod tytułem Willkommen in Deutschland. Entartete Musik) ${ }^{81}$.

Wspomniana wcześniej transmedialność jest również cechą charakterystyczną funkcjonowania zespołu, który korzysta z najnowszych mediów oraz technologii (opcja streamingu muzyki, zapis nagrań w formacie blu-ray, relacje online). Nie tylko koncerty - imprezy masowe są jak zaznacza Joanna Warońska ${ }^{82}$ analizowane również w kategorii współczesnej widowiskowości i audiowizualności również udział w programach telewizyjnych, audycjach radiowych, materiałach zamieszczonych w Internecie oraz bezpośredni kontakt $\mathrm{z}$ fanami podczas specjalnych „elitarnych” koncertów w ramach oryginalnego projektu Magical Mystery Tour $^{83}$ zwiększają siłę oddziaływania muzyki i działalność pro-bono zespołu. Występy w krajach bloku wschodniego (m.in. w NRD, Polsce, Czechosłowacji), a po rozpadzie ZSRR także w państwach posowieckich i post-reżimowych Ameryki Południowej (Argentyna) oraz bezpośredni kontakt z fanami i przedstawicielami mediów dodatkowo utrwalają pozytywny wizerunek zespołu i wzmacniają jego wysoką pozycję nie tylko w państwach niemieckojęzycznych.

${ }^{80}$ DTH, Zeit zu handeln, https://www.dietotenhosen.de/aktion (dostęp 06.01.2020 r.).

${ }^{81}$ Zespół Die Toten Hosen wystąpił gościnnie na koncertach, grając wspólnie z orkiestrą symfoniczną Robert Schumann Hochschule w Düsseldorfie. Efektem wspólnych występów jest dwupłytowy album „Entartete Musik“ Willkommen in Deutschland - ein Gedenkkonzert, Live Album, 2015. (C) 2015 (P) 2015 JKP Gmbh \& Co. KG.

${ }^{82}$ Por. A. Regiewicz, J. Warońska, Widowiskowość..., dz. cyt., s. 66-74.

${ }^{83}$ Nazwa trasy koncertowej nawiązuje do albumu płytowego oraz filmu zespołu The Beatles. Bezpłatne koncerty odbywają się w domach i mieszkaniach fanów. W 2017 roku taka kameralna muzyczna impreza odbyła się również w Polsce (w Poznaniu). 


\section{PODSUMOWANIE}

Paradygmat intermedialności w odniesieniu do utworów muzycznych odnosi się przede wszystkim do funkcjonowania dwóch kategorii: muzyczności i literackości, nawiązuje więc zarówno do wiedzy muzykologicznej, jak również literaturoznawczej i kulturowej. W związku z możliwością przedstawienia w artykule, który rządzi się określonymi zasadami dotyczącymi objętości, jedynie zarysu głównych pojęć i najistotniejszych problemów, skupiono się w powyższym tekście przede wszystkim na typologii Stevena Paula Schera - dotyczącej triady związków muzyczno-literackich - wraz z późniejszym rozwinięciem przez Andrzeja Hejmeja.

Muzyka punkrockowa - która mogłaby się wydawać mało ambitna i o niskim stopniu artyzmu i kunsztu zarówno muzycznego, jak i literackiego - wbrew pozorom jest bliska literaturze, a zwłaszcza liryce. W rozumieniu terminu przedstawionego przez Tomasza Górnego „muzyki programowej” utwory punkrockowe mieszczą się w ramach tego pojęcia. Słowa jako tekst literacki są ściśle zespolone z warstwą melodyczną, która w przypadku zespołu Die Toten Hosen powstaje pierwsza. Tekst jak palimpsest „nakłada się” na melodię. Ważny jest również ładunek emocjonalny zawarty w treści utworu oraz właściwej - dawniej prostej, obecnie już bardziej rozbudowanej i wzbogaconej różnorodnymi instrumentami także klasycznymi - linii melodycznej.

Mimo iż Jerzy Wertenstein-Żuławski i Mirosław Pęczak nie są przekonani co do cech literackich tekstów piosenek rockowych, to jednak wychodząc z perspektywy zarówno badań literackich (m.in. Jonathan Culler, Steven Knapp), jak również intermedialnych (m.in. Andrzej Hejmej, Magdalena Wasilewska-Chmura, Tomasz Górny), należy stwierdzić, że utwory muzyczne, w tym przedstawione powyżej punkrockowe piosenki Die Toten Hosen, posiadają znamiona literackości i można je również interpretować w kategorii relacji muzyczno-literackich, a przede wszystkim zaistnienia „literatury w muzyce” zaproponowanej przez Schera.

Ponadto nawiązując do słów Magdaleny Wasilewskiej-Chmury, iż: „Rozważając relacje intermedialne literatury i muzyki, należy mieć świadomość, że wykraczają one często poza związki binarne i wymagają uwzględnienia innych sztuk oraz koncepcji estetycznych, które wpływają na teorię i praktykę artystyczną"84,

${ }^{84}$ B. Wasilewska-Chmura, dz. cyt., s. 43. 
naszkicowane zostały w artykule - to zagadnienie wymaga z pewnością bardziej wnikliwej analizy w oddzielnym tekście - związki muzyki niemieckiego zespołu $\mathrm{z}$ nowymi mediami, oraz sposoby wykorzystania nowoczesnych technologii w nagrywaniu lub udostępnianiu utworów odbiorcom. Koncerty i realizowane przez muzyków medialne projekty, które wykorzystują nowoczesne technologie, można analizować również z perspektywy współczesnych audiowizualnych widowisk.

Z pewnością muzyka awangardowa - a taką jest punk rock - nie mieści się w standardowych normach i nie jest to muzyka łatwa do analizy porównawczej, ale intermedialność daje olbrzymią możliwość wyjścia poza schemat i pokazania sposobu funkcjonowania tekstu i melodii w sferze zarówno pozatekstowej, jak i pozamuzycznej, a także umożliwia pokazanie ich wzajemnych związków.

\section{BIBLIOGRAFIA}

\section{Literatura podmiotu}

Cytowane i wymienione teksty utworów muzycznych pochodzą z albumów płytowych:

a) Die Toten Hosen:

Alles ohne Strom, Studio Album, 2019, (C) 2019, (P 2019 JKP Gmbh \& Co. KG.

Ballast der Republik, Studio Album, 2012. (c) 2012 (P 2012 JKP Gmbh \& Co. KG.

„Entartete Musik“ Willkommen in Deutschland - ein Gedenkkonzert, Live Album, 2015. (c) 2015 (P) 2015 JKP Gmbh \& Co. KG.

Kauf mich, Studio Album, 1993 (2. wyd. 2007). (C) 1993, 2007 (P 1993, 2007 JKP Gmbh \& Co. KG.

Laune der Natur, Studio Album, 2017. (c) 2017 (P 2017 JKP Gmbh \& Co. KG.

Opel-Gang, Studio Album, 1983 (2. wyd. 2003). (C) 1983, 2003 (P 1983, 2003 JKP Gmbh \& Co. KG.

Opium fürs Volk, Studio Album, 1996 (2. wyd. 2007). (C) 1996, 2007 (P 1996, 2007 JKP Gmbh \& Co. KG.

b) The Sex Pistols:

Never Mind the Bollocks. Here's the Sex Pistols, Studio Album, 1977. (C) 1977 (P 1977 A\&M Records Ltd.

\section{Literatura przedmiotu}

Badzioch Bryła B., Pietruszewska-Kobiela G., Regiewicz A., Literatura - nowe media: homo irretitus w kulturze literackiej XX i XXI wieku, Wydawnictwo im. Stanisława Podobińskiego Akademii im. Jana Długosza, Częstochowa 2014.

Boucher D., Dylan i Cohen. Poeci rocka, przeł. J. Łoziński, Wydawnictwo Niebieska Studnia, Łódź 2016. 
Bourdieu P, Reguły sztuki. Geneza i struktura pola literackiego, przeł. A. Zawadzki, Universitas, Kraków 2001.

Castaldo G., Ziemia obiecana. Kultura rocka 1954-1994, przeł. J. Uszyński, Wydawnictwo Znak, Kraków 1997.

Culler J., Literatura w teorii, przeł. M. Maryl, Universitas, Kraków 2013.

Culler J., Teoria literatury. Bardzo krótkie wprowadzenie, przeł. M. Bassaj, Pruszyński i S-ka, Warszawa 1998.

Diederichsen D., Über Pop-Musik, Kiepenheuer \& Witsch, Köln 2014.

Geertz C., Dzieło i życie. Antropolog jako autor, przeł. E. Dżurak, S. Sikora, Wydawnictwo KR, Warszawa 2000.

Geertz C., Interpretacja kultur. Wybrane eseje, przeł. M.M. Piechaczek, Wydawnictwo Uniwersytetu Jagiellońskiego, Kraków 2005.

Górny T., Polifonia: od muzyki do literatury, Universitas, Kraków 2017.

Grochowski G., Tekstowe hybrydy. Literackość i jej pogranicza, Wydawnictwo FUNNA, Wrocław 2000.

Gwóźdź A. (red.), Pogranicza audiowizualności: parateksty kina, telewizji i nowych mediów, Universitas, Kraków 2010.

Hejmej A., Komparatystyka. Studia literackie - studia kulturowe, Universitas, Kraków 2013.

Hejmej A., Muzyczność dzieła literackiego, Wydawnictwo FUNNA, Wrocław 2001.

Higgins D., Intermedia i inne eseje, przeł. P. Rypson, Akademia Ruchu, Warszawa 1985.

Higgins D., Nowoczesność od czasu postmodernizmu oraz inne eseje, wybór, oprac. i posł. P. Rypson, Słowo/Obraz Terytoria, Gdańsk 2000.

IG Dreck auf Papier, Keine Zukunft war gestern: Punk in Deutschland, Archiv der Jugendkulturen Verlag, Berlin 2008.

Jessen K., Die Toten Hosen. Für immer Punk, Wilhelm Heyne Verlag, München 1997.

Knapp S., Literary Interest: The Limits of Anti-Formalism, Harvard University Press, Cambridge 1993.

Lewandowski M., Język subkultury punków, Wydawnictwo „Poznańskie Studia Polonistyczne", Poznań 2007.

Markowski M.P., Nycz R. (red.), Kulturowa teoria literatury. Główne pojęcia i problemy, Universitas, Kraków 2012.

Meinert P., Seeliger M., Punk in Deutschland, Sozial- und kulturwissenschaftliche Perspektiven, Transcript Verlag, Bielefeld 2013.

Michalski D., Rock przez cały rock, Wiedza Powszechna, Warszawa 1990.

Müller J.E., Intermedialität. Formen moderner kultureller Kommunikation, Nodus, Münster 1996.

Niedermayr S., Scheib Ch., Im Osten - neue Musik Territorien in Europa. Reportagen aus Ländern im Umbruch, PFAU-Verlag, Saarbrücken 2002.

Oehmke P., Die Toten Hosen. Am Anfang war der Lärm, Rowohlt Taschenbuch Verlag, Reinbek bei Hamburg 2015.

Ong W.J., Oralność i piśmienność. Słowo poddane technologii, przeł. J. Japola, Wydawnictwo Uniwersytetu Warszawskiego, Warszawa 2011. 
Pierzchała P., Polska piosenka pop jako tekst w tekście kultury: na przykładach z pierwszej dekady XXI wieku, Wydawnictwo Uniwersytetu Śląskiego, Katowice 2016.

Piesiewicz P.F., Utwór muzyczny i jego twórca, Wolters Kluwer Polska, Warszawa 2009.

Regiewicz A., Warońska J., Widowiskowość i audiowizualność $w$ dobie ponowoczesności, Wydawnictwo Akademii im. Jana Długosza w Częstochowie, Częstochowa 2012.

Regiewicz A., Warońska J., Żywiołek A., Muzyka w czasach ponowoczesnych, Wydawnictwo im. Stanisława Podobińskiego Akademii im. Jana Długosza, Częstochowa 2013.

Turner S., Głód niebios. Rock \& roll. W poszukiwaniu zbawienia, przeł. T. Bieroń, Wydawnictwo Znak, Kraków 1997.

Walas T., Nycz R. (red.), Kulturowa teoria literatury 2. Poetyki, problematyki, interpretacje, Universitas, Kraków 2012.

Wasilewska-Chmura M., Przestrzeń intermedialna literatury i muzyki: muzyka jako model i tworzywo w szwedzkiej poezji późnego modernizmu i neoawangardy, Wydawnictwo Uniwersytetu Jagiellońskiego, Kraków 2011.

Wertenstein-Żuławski J., Pęczak M., Tekst piosenki rockowej, stopnie zależności od kultury dominującej i treści przekazu, [w:] Spontaniczna kultura młodzieżowa, J. Wertenstein-Żuławski, M. Pęczak (red.), Wydawnictwo Wiedza o Kulturze, Wrocław 1991, s. 253-267.

Wolf W., The Musicalization of Fiction: A Study in the Theory and History of Intermediality, Rodopi, Amsterdam - Atlanta 1999.

Zieliński P., Scena rockowa w PRL. Historia, organizacja, znaczenie, Wydawnictwo Trio, Warszawa 2005.

\section{Źródła internetowe}

Bei der lit. Cologne „Tote Hosen“ - Sänger Campino: Wir machen ein neues Album, https:// www.express.de/duesseldorf/bei-der-lit-cologne--tote-hosen--saenger-campino-wir-machen-ein-neues-album-23704206

https://de-de.facebook.com/dietotenhosen/

https://www.dietotenhosen.de/

http://www.heute.at/szene/musik/story/-Tote-Hosen--vor-Wien-Gig---Mittelfingerfuer-Terror--41397655

Leserkommentare, http://www.taz.de/30-Jahre-Die-Toten-Hosen/!5096509/

Mackiewicz Ł., Cechy dzieła literackiego - co sprawia, że tekst jest dziełem „literackim”?, http://www.ekorekta24.pl/cechy-dziela-literackiego-co-sprawia-ze-tekst-jestdzielem-literackim/

The Nobel Prize in Literature 2016. Nobelprize.org. Nobel Media AB 2014, http://www. nobelprize.org/nobel_prizes/literature/laureates/2016/

Wirth S., Lit. Cologne. Campino und das Dichten, http://stellwerk-magazin.de/magazin/ artikel/2016-03-23-campino-und-das-dichten

Zeit zu handeln, https://www.dietotenhosen.de/aktion 


\section{Biogram}

Doktor nauk humanistycznych, pracownik naukowy Instytutu Literaturoznawstwa Uniwersytetu Humanistyczno-Przyrodniczego im. Jana Długosza w Częstochowie. Zainteresowania badawcze: analiza kulturowa tekstów literackich, motyw wielokulturowości, twórczość niemieckojęzycznych noblistek, audiowizualność i intermedialność literatury i muzyki. Autorka publikacji m.in.: Recepcja prozy Herty Müller w Polsce (monografia), Herta Müller. Pisarka „obcego spojrzenia” (rozdział w monografii), „Weil das Schreiben ein stummes Tun ist...". Politische Essays von Elfriede Jelinek und Herta Müller (współautorstwo rozdziału w monografii), Dyskurs postkolonialny w literaturze niemieckiej, ze szczególnym uwzględnieniem literatury niemiecko-tureckiej (artykuł).

ORCID: 0000-0002-7340-6525 